\title{
PEMBERDAYAAN MASYARAKAT MELALUI OPTIMALISASI PENGELOLAAN WAKAF TUNAI (Studi Kasus pada LAZ Baitul Maal Hidayatullah dan Yatim Mandiri Cabang Lampung)
}

\author{
Ruslan Abdul Ghofur \\ Dosen Institut agama Islam Negeri (IAIN) Raden Intan Lampung \\ rghofur@yaboo.com \\ Isnayati Nur \\ Dosen Institut agama Islam Negeri (IAIN) Raden Intan Lampung \\ iznha40@yaboo.com
}

\begin{abstract}
This research includes into field research using descriptive comparative-analytic method compare two cash donation management institutions Baitul Maal Hidayatullab and Yatim Mandiri branch of Lampung from managerial aspects and its management. From the research it was found that the managerial aspects, both institutions have been carrying out management functions well, although there are still many obstacles encountered. Constraints that exist are more focused on positioning discrepancy employees that do not comply with the expertise that is not equally effective. In funding aspect and utilization of cash donation is still traditionally and consumer organized, because the funding model was only intended to supplement the inventory donation asset that have been there without doing more innovations especially in the field of public economics.
\end{abstract}

Key words: Managerial, Cash Donation, Management

\begin{abstract}
Abstrak
Penelitian ini termasuk ke dalam penelitian lapangan yang menggunakan metode deskriptif komparatif-analitik dengan membandingkan dua lembaga pengelola wakaf tunai Baitul Maal Hidayatullah dan Yatim Mandiri Cabang Lampung dari aspek manajerial dan pengelolaanya. Dari hasil penelitian ditemukan bahwa pada aspek manajerial, kedua lembaga tersebut telah melaksanakan fungsi manajemen dengan baik, meskipun masib banyak kendala yang dihadapi. Kendala yang ada lebih terfokus pada ketidaksesuain penempatan posisi karyawan yang tidak sesuai dengan keabliannya sebingga tidak efektif. Pada aspek pendanaan dan pendayagunaan wakaf tunai masib bersifat tradisional dan konsumtif, karena model pembiayaan yang dilakukan banya bertujuan untuk melengkapi inventaris aset wakaf yang telab ada tanpa melakukan inovasi yang lebih terutama pada bidang ekonomi masyarakat.
\end{abstract}

Kata kunci: Pengelolaan, Wakaf Tunai, Manajemen 


\section{Pendahuluan}

Islam merupakan agama yang memiliki nilai-nilai istimewa yang berbeda dengan agama-agama samawi yang lainnya. Islam memuat aturan-aturan di segala aspek kehidupan baik bernegara maupun bermasyarakat. Salah satu aturan yang dijelaskan secara komprehensip adalah aspek perekonomian, terutama yang menyangkut kebutuhan masyarakat secara luas seperti halnya zakat, wakaf dan waris karena Islam sangat menentang kemiskinan. Wakaf merupakan salah satu instrument lembaga keuangan Islam di samping zakat, infak dan shadaqah, yang telah lama hadir di bumi Indonesia.

Sejak datangnya agama Islam di Indonesia pada abad ke-7 Masehi, perwakafan berlaku dalam masyarakat Indonesia berdasarkan hukum Islam dan hukum adat, meski belum ada peraturan perundangan tertulis yang mengaturnya. Wakaf yang ada pada masa itu adalah wakaf berupa benda tidak bergerak berupa bangunan. Wakaf dalam perkembangannya menjadi salah satu instrumen sosial Islam yang mengandung nilai sosial-ekonomi dan merupakan bentuk perwujudan keadilan sosial dalam Islam dan juga sebagai penunjang pembangunan ekonomi. Demikian pula dengan adanya beberapa peraturan Perundang-undangan yang dikeluarkan oleh Pemerintah, maka lembaga wakaf secara kelembagaan diatur oleh Negara (Juhaya S. Praja, 1997:1-5).

Menurut data Badan Wakaf Indonesia jumlah seluruh tanah wakaf di Indonesia sebanyak 2.686.536.565,68 $\mathrm{m}^{2}$ yang tersebar di 366.595 lokasi (www.bwi.or.id). Jumlah wakaf yang begitu banyak sebenarnya sudah dikelola oleh lembaga pengelola wakaf. Namun ironisnya, harta wakaf tersebut masih banyak yang terbengkalai dan tidak diberdayakan.

Selama ini, pemahaman wakaf lebih dititikberatkan pada properti dan bangunan yang sifatnya statis serta sulit untuk dikembangkan. Manfaat wakaf tanah dan bangunan itu hanya dinikmati oleh masyarakaf yang berdomisili di sekitar harta wakaf berada. Sementara kebutuhan masyarakat begitu banyak, sehingga dibutuhkan sumber pendanaan tunai yang tidak terikat tempat dan waktu (Nur Fadhilah, 2009: 160-172). Berdasarkan prinsip tersebut, 
maka dibuatlah inovasi produk wakaf yaitu wakaf tunai. Bentuk wakaf yang tidak hanya berupa properti melainkan wakaf dengan dana (uang) tunai. Usaha untuk me-revitalisasi unsur wakaf guna memberikan berbagai macam manfaat ekonomi memerlukan terobosan pemikiran tentang konsep tersebut yang sesuai dengan perkembangan yang ada tetapi tidak meninggalkan unsur syariah (M.A. Mannan, 2001:94).

Di Indonesia, Wakaf uang (cash waqf) sebagaimana yang telah diperbolehkan oleh kalangan ulama, telah mendapat legitimasi setelah dikeluarkannya fatwa MUI tanggal 11 Mei 2002. Dengan demikian, kran wakaf menjadi terbuka lebar dan umat Islam menjadi semakin mudah untuk mewakafkan sebagian harta miliknya. Menyusul kemudian UU No. 41 Tahun 2004 tentang Wakaf dan Peraturan Pemerintah RI No. 42 Tahun 2006 tentang pelaksanaan Undang-undang Nomor 41 Tahun 2004 tentang Wakaf yang didalamnya mengatur tentang wakaf benda bergerak telah disahkan.

Wakaf tunai memiliki tingkat fleksibilitas yang sangat tinggi, artinya wakaf tunai dapat dikembangkan dengan berbagai kegiatan usaha produktif, juga dapat dilakukan oleh siapa pun masyarakat, tanpa harus menunggu kaya terlebih dahulu. Sedemikian itu urgennya wakaf tunai, maka jika tidak dikelola dengan sebaikbaiknya, potensi wakaf yang sangat besar ini akan hanya menjadi sebuah impian belaka. Bila dikelola secara professional, wakaf dapat dipergunakan untuk menciptkan kemandirian umat. Semakin baik pengelolaannya, semakin besar peluang untuk sukses.

Untuk mencapai pengelolaan yang optimal, maka perlu dilakukan studi tentang pengelolaan perwakafan. Kemajuan dan kemunduran wakaf tunia/uang di Indonesia sangat ditentukan oleh kemampuan manajemen para pengelolanya. Nazhir dan Lembaga Keuangan Syariah Pengelola Wakaf Uang (LKS-PWU). Selain masalah aplikasi, nazhir masih memerlukan upgrading pengetahuan manajemennya. Secara garis besar, manajemen memiliki empat unsur yaitu planning (perencanaan), organizing (pengorganisasian), directing (pengarahan), dan controlling (pengontrolan). Ketiganya merupakan tahapan manajemen yang 
saling mempengaruhi (Muhyar Fanani, 2010: 183-184). Di samping pengembangan yang tetap harus mengindahkan prinsip-prinsip umum syariah dalam kegiatan ekonomi (Muhyar Fanani, 2010: 139).

Pada saat ini, di Indonesia telah banyak berdiri lembagalembaga sosio-ekonomi keagamaan yang tersebar di berbagai daerah di Indonesia seperti Dompet Dhuafa dengan Tabung Wakafnya, Wakaf Tunai Muamalat (Waqtumu), LAZ Baitul Maal Hidayatullah, Yatim Mandiri dan lain-lain. Dari beberapa lembaga tersebut telah merealisasikan wakaf tunai sebagai salah satu programnya sehingga membuat kegiatan wakaf ini menjadi terorganisir secara efisien sehingga dapat memberikan hasil yang optimal. Dari fenomena munculnya banyak organisasi pengelola wakaf maka penting untuk menganalisa pengelolaan wakaf tunai pada organisasi pengelola wakaf agar pemberdayaan masyarakat muslim dapat dilakukan secara optimal. Oleh sebab itu, pertanyaan penelitian yang diajukan dalam tulisan ini ialah bagaimana optimalisasi pengelolaan wakaf tunai pada LAZ Baitul Maal Hidayatullah dan Yatim Mandiri di Lampung?

Secara metodelogis, penelitian ini termasuk ke dalam penelitian lapangan (field Research), dengan objek penelitiannya ialah lembaga-lembaga sosio-ekonomi keagamaan pengelola wakaf tunai. Secara khusus lembaga yang diteliti adalah LAZ Baitul Maal Hidayatullah Cabang Lampung dan Yatim Mandiri Cabang Lampung. Penelitian ini bersifat deskriptif komparatif analitik, yaitu memberikan deskripsi mengenai lembaga pengelola wakaf tunai, dalam hal ini LAZ Baitul Maal Hidayatullah dan Yatim Mandiri Lampung. Sedangkan metode komparatif analisis digunakan dalam membandingkan kedua lembaga tersebut, serta menganalisa kesesuiannya dengan teori-teori dalam Ekonomi Islam.

Penelitian ini menggunakan dua sumber data yaitu pertama, data primer yang diperoleh secara langsung dari objek penelitian Kedua, data sekunder yang diperoleh dari data-data hasil penelitian terdahulu dan informasi lain yang diambil dari buku, majalah, internet dan lain-lain. Metode analisis data yang digunakan adalah metode berfikir induktif. Analisis berangkat dari data yang diperoleh dari penelitian secara rinci tentang pengelolaan dana wakaf tunai 
pada Baitul Maal Hidayatullah dan Yatim Mandiri Cabang Lampung kemudian menarik kesimpulan umum mengenai pengelolaan wakaf tunai pada kedua lembaga tersebut.

\section{Landasan Hukum dan Manajemen Pengelolaan Wakaf Tunai}

Sebagai suatu teori, konsep wakaf tunai tidak lekang dari eklektikisme teori pokok tentang wakaf itu sendiri. Secara akar bahasa,

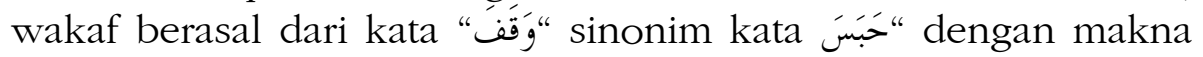
aslinya berhenti, diam di tempat, atau menahan. Kata al-waqfadalah bentuk masdar (gerund) dari ungkapan waqfu al-syai', yang berarti menahan sesuatu. Sebagai kata benda, kata wakaf semakna dengan kata al-habs. Kalimat: habistu abbisu habsan dan kalimat: abbastu ubbisu abbaasan, maksudnya adalah waqaftu (menahan) (Abdul Ghafur Anshori, 2006:7).

Dari segi istilah wakaf diartikan sebagai suatu jenis pemberian yang dilakukan dengan cara menahan (kepemilikan) untuk dimanfaatkan guna kepentingan umum (Sayid Imam Muhammad Ibn Ismail al-Kahlani, tt: 87). Adapun yang dimaksud menahan kepemilikan asal ialah menahan barang yang diwakafkan agar tidak diwariskan, digunakan, disewakan, dijual, dihibahkan, digadaikan, dipinjamkan, dan sejenisnya. Sedangkan pemanfaatannya adalah dengan menggunakan sesuai dengan kehendak pemberi wakaf tanpa imbalan (Muhammad Jawad Mughniyah, 1996:635). Adapun Wakaf uang (cash waqf/waqf al-nuqud) adalah wakaf yang dilakukan seseorang, kelompok orang, lembaga, atau badan hukum dalam bentuk uang. Dengan kata lain, wakaf uang merupakan perbuatan hukum Wakif untuk memisahkan dan/atau menyerahkan sebagian harta benda miliknya yang berupa uang untuk dimanfaatkan selamanya atau untuk jangka waktu tertentu, sesuai dengan kepentingannya guna keperluan ibadah dan/atau kesejahteraan umum menurut syariat (Sarmidi Husna, 2013).

Komisi Fatwa Majelis Ulama Indonesia (MUI) juga membolehkan wakaf tunai. Pada tahun 2002 dikeluarkan fatwa tentang Wakaf Uang yang isinya, Wakaf uang (cash wakaf/wagfal-nuqud) adalah wakaf yang dilakukan seseorang, kelompok orang, lembaga, atau badan hukum dalam bentuk uang tunai, Termasuk ke dalam 
pengertian uang adalah surat-surat berharga.

Wakaf termasuk infaq fi sabilillah, maka dasar yang digunakan para ulama dalam menerangkan konsep wakaf ini didasarkan pada keumuman ayat-ayat Al-Qur'an yang menjelaskan infaqfi sabilillah. Diantara ayat-ayat tersebut antara lain yaitu surat Ali-Imran ayat 92 yang artinya:

"Kamu sekali-kali tidak sampai kepada kebajikan (yang sempurna), sebelum kamu menafkahkan sehahagian harta yang kamu cintai. dan apa saja yang kamu nafkahkan Maka Sesungguhnya Allah mengetahuinya".

Dalam sebuah hadits:

"Telah menceritakan Yahya bin Yahya At-Tamimi, telah mengabarkan Salim bin Akhdar dari 'Auni Nafi'I dari Ibnu Umar r.a berkata, bahwa sahabat Umar r.a memperoleh sebidang tanah di Khaibar, kemudian menghadap kepada Rasulullah, saya mendapatkan sebidang tanah di Khaibar, saya belum pernah mendapatkan harta sebaik itu, maka apakah yang engkau perintahkan kepadaku? Rasulullah menjawab: bila kamu suka, kamu tahan (pokoknya) harta itu, dan kamu sedekahkan (hasilnya). Kemudian Umar melakukan shadaqah, tidak dijual dan tidak dihibahkan dan tidak pula diwariskan. Ibnu Umar berkata: Umar menyedekahkannya kepada orang fakir, kaum kerabat, budak belian, sabilillah, ibn sabi dan tamu. Dan tidak dilarang bagi orang yang menguasa tanah wakaf itu (mengurus) untuk mengambil nafkah sederhana/memakannya dari hasilnya dengan cara yang bail (sepantasnya) dan memberi makan teman-teman tanpa berlebihan".

Dalam pelaksanaan wakaf di Indonesia mengacu pada pasal 6 Undang-undang Nomor 41 Tahun 2004 tentang wakaf, beberapa rukun/unsur yang harus dipenuhi sebagai berikut: orang yang berwakaf (Wakif), harta yang diwakafkan (Mauquf), tempat ke mana diwakafkan harta itu/tujuan wakaf (Mauquf 'alaib), akad/ pernyataan wakaf (sighat). Di samping itu, ada 2 (dua) hal yang menjadi perhatian, yaitu pengelola wakaf (Nazhir) dan jangka waktu yang tak terbatas.

Diantara manfaat wakaf tunai dapat diidentifikasi yaitu:

1. Wakaf tunai tidak ditentukan jumlah dan besarannya.

2. Dana wakaf tunai dapat diberdayakan untuk memelihara dan 
pembangunan gedung-gedung sekolah yang bersumber dari wakaf.

3. Harta wakaf tunai dapat membantu lembaga-lembaga Islam yang terkadang mengahadapi kendala financial.

4. Wakaf tunai menjadi kekuatan Umat Islam dalam kemandirian financial sehingga dapat memberdayakan di bidang pendidikan, ekonomi, hukum, kesehatan dan lain.

Perlu untuk diperhatikan bahwa kemajuan dan kemunduran wakaf tunai di Indonesia akan sangat ditentukan oleh kemampuan manajemen para pengelolanya. Nazhir dan Lembaga Wakaf adalah ujung tombak pengembangan wakaf tunai, sehinggga kemampuan dalam aspek manajemen menjadi suatu keharusan. Manajemen berfungsi mengurangi hambatan-hambatan dalam mencapai suatu tujuan sebagaiman yang telah diingatkan oleh Ali bin Abi Thalib yang artinya bahwa kebaikan tanpa organisasi akan terkalahkan oleh kejahatan yang terorganisir (Al-Hasyimi, 34).

Di bawah ini diuraikan empat fungsi manajemen yang sangat menentukan dan strategis yang dapat dikembangkan dan diterapkan pada pengelolaan wakaf tunai;

Pertama, perencanaan atau planning, adalah kegiatan awal dalam sebuah pekerjaan dalam bentuk memikirkan hal-hal yang terkait dengan pekerjaan itu agar mendapat hasil yang optimal. Dalam Islam planning dikenal dengan istilah musyawarah, dengan demikian, planning adalah proses yang menyangkut upaya yang dilakukan untuk mengantisipasi kecenderungan di masa yang akan datang dan penentuan strategi dan taktik yang tepat untuk mewujudkan target dan tujuan organisasi (Farid Wadjdy dan Mursyid, 2007:176). Kedua, pengorganisasian (Organizing) yaitu struktur dari wewenang atau kekuasaan nazhir atau bisa diartikan dengan suatu kerangka tingkah laku untuk analisis proses pengambilan keputusan organisasi sehingga struktur organisasi menjadi tangguh dan yang lebih penting lagi adalah bagaimana semua pihak yang terlibat dalam organisasi bisa bekerja secara efektif dan efisien guna mencapai tujuan organisasi (Farid Wadjdy dan Mursyid, 2007:177).

Ketiga, fungsi pengarahan (directing), yang merupakan 
proses implementasi program agar bisa dijalankan oleh seluruh pihak (para nazhir) dalam organisasi serta proses memotivasi agar semuanya dapat menjalankan tanggung jawab dengan penuh kesadaran dan produktivitas tinggi. Keempat, fungsi pengawasan (controlling) sebagai suatu proses yang dilakukan untuk memastikan seluruh rangkaian kegiatan yang telah direncanakan, diorganisasikan, dan diimplementasikan bisa berjalan sesuai dengan target yang diharapkan sekalipun berbagai perubahan terjadi. Pengawasan harus ada dalam pengelolaan wakaf yang meliputi segala kegiatan penelitian, pengamatan dan pengukuran terhadap jalannya operasi berdasarkan rencana yang ditetapkan dengan standar yang diminta, melakukan tindakan koreksi penyimpangan, perbandingan antara hasil (output) yang dicapai dengan masuknya (input) yang digunakan.

Aspek penting lainnya yang harus menjadi perhatian dalam pengelolaan wakaf tunai secara profesional adalah aspek Sumber Daya Insani (SDI) para pengelola. SDI diharapkan mampu menunjukkan kinerja yang optimal. Para karyawan diharapkan mampu meningkatkan kompetensi dan kemampuan teknis guna merealisasikan tujuan yang telah ditetapkan dalam perencanaan. Kegiatan manajemen sumber daya insani adalah seputar penentuan aktivitas karyawan, seleksi calon karyawan, pelatihan dan pengembangan karyawan serta aktivitas lain terkait dengan awal masuk karyawan hingga pensiun (Ahmad Ibrahim Abu Sinn, 2006: 105).

Hubungan antar karyawan dalam sebuah organisasi merupakan aspek penting untuk memenuhi kebutuhan mereka yang bersifat non-materi (kejiwaan, spiritual). Jika kebutuhan spiritual ini dapat terpenuhi, akan mendorong dan memotivasi pegawai untuk bekerja lebih optimal. Mereka melakukan itu semua dengan penuh keikhlasan dan semangat saling membantu satu sama lain. Selain itu, budaya organisasi juga memberikan pengaruh yang besar dalam suatu lembaga tidak terkecuali lembaga wakaf. Organisasi pada intinya adalah interaksi-interaksi orang dalam sebuah wadah untuk melakukan sebuah tujuan yang sama. Dalam Islam, organisasi merupakan suatu kebutuhan.

Di samping pola manajemen dalam lembaga wakaf harus terdapat pula model pengelolaan, yang terdiri dari pendanaan dan 
pembiayaan. Pendanaan merupakan suatu usaha penggalangan dana masyarakat yang dilakukan oleh nazdir. Di dalam dunia penggalangan dana sosial dikenal dengan adanya "prinsip 80-20". Rumus ini mengkalkulasikan bahwa sebanyak 80\% dukungan dana bagi suatu lembaga lazimnya berasal dari donasi personal tertentu dengan skala ekonomi yang mapan, sedangkan sisanya yang 20\% berasal dari umat. Artinya mayoritas pendanaan suatu organisasi sosial pada umumnya berasal dari segelintir orang dengan nominal jauh lebih besar dari umumnya penggalangan dana yang berasal dari masyarakat umum (kotak amal) (Zaim Saidi dan Hamid Abidin, 2005: 56).

Dalam upaya penggalangan dana, secara garis besar, teknik penggalangan dana dilakukan dengan dua cara, yakni promosi dan pelayanan.. Promosi wakaf uang bertujuan memberitahukan, menyadarkan, mengingatkan, mendorong, dan memotivasi masyarakat untuk berwakaf. Untuk memperoleh wakaf baru, dapat dilakukan melalui berbagai pendekatan. Pendekatan diarahkan pada calon wakif baru baik berupa individu, perusahaan (company), korparasi (organisasi bisnis), NGO, lembaga, dll (Muhyar Fanani, 2010: 110).

Pada aspek pembiayaan atau pendayagunaan, yang merupakan proes pemanfaatan atau penyaluran dana wakaf, yang berfungsi untuk menjamin kelanggengan harta wakaf agar dapat terus memberikan pelayanan prima sesuai dengan tujuannya. Pendayagunaan berarti kemampuan mendatangkan hasil dan manfaat, efisien, tepat guna, yang hampir sama dengan makna pemanfaatan, yakni pengusahaan agar mampu mendatangkan hasil (Departemen Pendidikan dan Kebudayaan, 1998: 189).

Menurut Mundzir Qahaf, gagasan menyisihkan sebagian pendapatan wakaf untuk modal harta tetap wakaf tidak dibahas dalam fikih klasik. Oleh karena itu, Qahaf membedakan pembiayaan proyek wakaf ke dalam model pembiayaan harta wakaf tradisional dan model pembiayaan baru wakaf secara institusional (Direkotorat Pemberdayaan Wakaf, 2007: 78-79). Dalam model pembiayaan harta wakaf tradisional, terdapat lima model pembiayaan rekonstruksi harta wakaf, yaitu : pinjaman, hurk (kontrak sewa jangka panjang dengan pembayaran lump sum yang cukup besar dimuka), al-ijaratain (sewa dengan dua pembayaran), menambah harta wakaf baru, dan 
substitusi harta wakaf. Model-model tersebut hanya penambahan harta wakaf baru yang terbukti mampu mengembangkan modal wakaf dan peningkatan kapasitas produksi. Sementara model yang lain cenderung bersifat membiayai operasional dan mengembalikan produktifitas harta wakaf.

Dalam Model investasi Proyek Wakaf secara Institusional, model wakaf ini dikembangkan dengan sistem kelembagaan dengan mengikuti perkembangan lembaga-lembaga keuangan syari'ah. Harta wakaf dapat diinvestasikan pada lembaga keuangan syariah sebagai pembiayaan suatu proyek yang menguntungkan. Model sepeti ini dapat berupa murabahah, istisna', ijarah, dan mudharabah.

\section{Analisis}

\section{Baitul Maal Hidayatullah}

1. Gambaran umum dan pola manajemen Baitul Maal Hidayatullah

Baitul Maal Hidayatullah (BHM), yang kemudian dikenal dengan sebutan BMH adalah Lembaga Amil Zakat Nasional yang berdiri pada tanggal 26 Februari 2002 dengan akta notaris Lilik Kristiwati, S.H Nomor 001 tahun 2001. Dan mendapatkan SK dari Menteri Agama No. 538 tahun 2001, yang dipelopori oleh Muhammad Arif Sufia Gandadipura. Mulanya BMH adalah bagian dari instansi pesantren Hidayatullah yang bertugas mendanai kebutuhan-kebutuhan pesantren. Seiring dengan makin luasnya bidang garap dan berubahnya pesantren Hidayatullah dari organisasi pendidikan dan sosial menjadi organisasi massa, maka BMH pun dideklarasikan sebagai Lembaga Amil Zakat Nasional (LAZ BMH Cabang Lampung 2013).

Tahun 2009, Lembaga Amil Zakat Baitul Maal Hidayatullah Cabang Lampung resmi berdiri berdasarkan SK notaris untuk wilayah Lampung Tahun 2009 sebagai lembagai lembaga amal usaha, dan memutuskan Imam Mahmud sebagai Ketua LAZ Baitul Maal Hidayatullah cabang Lampung. Dalam kesehariannya BMH Cabang Lampung menghimpun dana dari masyarakat berupa zakat, infaq, waqaf, hibah dll. Selanjutnya BMH menyalurkan kepada 
yang berhak menerimanya sesuai dengan program-program yang dicanangkan.

Dilihat dari fungsi manajemennya, yaitu perencanaan, pengorganisasian, pengarahan, dan pengawasan, BMH cabang Lampung sebagai lembaga amal usaha telah menjalankan keempat fungsi tersebut. Tujuan adanya program wakaf tunai adalah untuk pengembangan lembaga pendidikan atau pesantren dalam bentuk pembebasan lahan dan juga menyediakan sarana dan prasarana pendidikan yang ditujukan untuk membantu kaum dhuafa. Dalam membuat perencanan, BMH mengadakan musyawarah dengan para pengurus divisi juga dengan pengurus PW atau PD BMH Lampung. Program yang dilaksanakan disesuaikan dengan kebutuhan masyarakat sehingga program yang direncanakan dapat diterima dan dilaksanakan oleh masyarakat dengan optimal.

Dalam melakukan penyusunan perencanaan, setiap tahun BMH melakukan kegiatan RAKERNAS. Rapat Kerja Nasional ini di hadiri oleh seluruh pengurus BMH se-Indonesia. Dalam rapat ini disusun rancangan kegiatan dan program jangka panjang yang akan dilaksanakan oleh BMH di masa depan. BMH Cabang mempunyai kewajiban untuk menyusun Rencana Induk Pengembangan (RIP), rencana kegiatan dan Anggaran (RKAT)

Dalam pengorganisasian, BMH Cabang Lampung telah melaksanakan fungsi ini. Dapat dilihat dari adanya susunan struktur organisasi, pendelegasian wewenang dan tanggung jawab yang jelas dan terstruktur yang terdiri dari Dewan Pengurus Syariah, Pengawas Manajemen, struktur manajemen yang meliputi: Ketua Lembaga dan seluruh devisi-devisi dibawahnya. Dilihat dari struktur organisasinya, struktur BMH Cabang Lampung termasuk organisasi lini yang bercirikan: skala organisasi yang masih kecil, jumlah karyawan yang masih sedikit dan spesialisasi yang masih sedikit pula.

Bentuk pengawasan yang dilakukan $\mathrm{BMH}$ adalah selain pengawasan internal juga pengawasan eksternal yaitu pengawasan secara dengan adanya rapat evaluasi mingguan yang tidak hanya bertujuan untuk memberikan motivasi kepada pengurus tetapi juga untuk melihat berjalannya kinerja pengurus divisi selama satu pekan. 


\section{Pengelolaan Wakaf Tunai BMH}

Pengelolaan wakaf tunai pada BMH cabang Lampung, terdiri dari penghimpunan dan pembiayaan. Dalam pengelolaan wakaf tunai, yang menjadi sasaran penghimpunan adalah lembaga, perusahaan atau instansi yang berbadan hukum dan masyarakat umum baik perorangan maupun kelompok. Terdiri atas perusahaanperusahaan swasta dan BUMN, Departemen Pemerintahan, Lembaga Donor (LSM), perbankan dan masyarakat umum baik di dalam maupun di luar negeri. Penghimpunan dana wakaf tunai di BMH dilakukan oleh divisi yang bergerak di bidang Fundraising. Dana wakaf tunai pada $\mathrm{BMH}$ dihimpun dari para donatur donatur tetap maupun insidentil. Hal ini merupakan hasil dari sosialisasi program yang dilakukan oleh para pengurus BMH baik secara langsung maupun melalui media-media (Imam Mahmud, BMH Lampung: 2013).

BMH merupakan lembaga amal usaha yang mendapat legalitas sebagai Lembaga Amil Zakat. Pendayagunaan hasil wakaf mencakup aktifitas yang luas. Walaupun pemberdayaan masyarakat (miskin) selalu menjadi prioritas. Jika melihat pola pendayagunaan harta wakaf maka model pemberdayaan wakaf tunai yang di BMH cabang Lampung adalah model pendayagunaan/pembiayaan wakaf tradisional, dimana model-model pembiayaan yang dikembangkan hanya menambah harta wakaf baru dan substitusi harta wakaf.

Secara umum dana wakaf tunai yang telah terkumpul digunakan untuk pembebasan lahan dalam rangka mengembangkan yayasan Hidayatullah yang berpusat di Mataram baik untuk pendidikan formal maupun non formal. Dana yang diperoleh diserahkan langsung kepada $\mathrm{BMH}$ Pusat untuk pengembangan lembaga pendidikan yang berada di bawah naungan PP Hidayatullah. BMH cabang Lampung hanya bertugas menghimpun dana dan kemudian menyerahkan pengelolaan kepada BMH Pusat (M. Yudi, BMH Lampung: 2013).

Pendayagunaan dana BMH cabang Lampung bahwa dana keseluruhan dari zakat dan infak tidak terikat yang masuk ke BMH cabang, setelah dikurangi pendayagunaan melaui BMH Pusat sebesar: (BMH, 2013). 
a. $10 \%$ dari dana zakat

b. $5 \%$ dari dana infak

Dan hak amil setempat:

a. Zakat $12,5 \%$

b. Infak 30\% (25\% untuk hak amilCabang, 5\% untuk BMH pusat)

Dana yang telah diserahkan kepada pusat akan dilaporkan setiap bulannya dalam bentuk laporan keuangan akhir bulan. Selain diserahkan kepada pusat, BMH Cabang mempunyai kewajiban sendiri untuk mengembangkan lahan di daerah dimana kantor cabang berada sebagai sarana pendidikan formal yang berupa Sekolah Dasar Integral dan pendidikan non formal Taman Pendidikan Al-Qur'an. Untuk saat ini, tanah yang telah dibebaskan kurang lebih sekitar 4,5 Ha yang tersebar di beberapa daerah di Provinsi Lampung (BMH Lampung, 2013).

\section{Yatim Mandiri Cabang Lampung}

1. Gambaran umum dan pola manajemen Yatim Mandiri

Yatim Mandiri yang berdiri pada tanggal 31 Maret 1994 menggunakan nama Yayasan Pembinaan dan Pengembangan Panti Asuhan Islam dan Anak Purna Asuh (YP3IS) lahir dari sebuah ide beberapa aktivis yang peduli terhadap kondisi panti asuhan di Surabaya. Berbagai catatan perjalanan telah terhimpun. Baik yang berkaitan dengan legalitas maupun operasional kesehariannya. Diantaranya; sesuai dengan undang-undang nomor 16 tahun 2000 tentang yayasan batas toleransi penyesuaiannya adalah tahun 2005, sehingga demi kepentingan publik yayasan harus melakukan pendaftaran ke Depkumham Pusat di Jakarta. Depkumham menolak karena nama YP3IS telah digunakan oleh pihak lain. Catatan yang lain, nama YP3IS terlalu panjang kurang bisa memberikan fungsi branding yang marketable dalam pengembangan publikasi lembaga ke masyarakat (Yatim Mandiri, 2013).

Maka dengan dorongan masyarakat dan hasil analisa internal, diubahlah menjadi nama yang sederhana dan sarat dengan makna, yaitu Yayasan Yatim Mandiri, dengan akronim Yatim Mandiri. Dengan nama ini, telah terdaftar di Depkumham dengan nomor: 
AHU-2413.AH.01.02.2008. Kemudian yayasan Yatim Mandiri, memberikan gagasan untuk mendirikan cabang Yatim Mandiri di berbagai Daerah salah satu nya di Lampung. Maka dengan gagasan tersebut, pada bulan Maret 2013 Yatim Mandiri Cabang Lampung resmi dibuka(Yatim Mandiri, 2013).

Dalam melaksanakan fungsi perencanaan, Yatim Mandiri melakukan perencanaan melalui wadah musyawarah antara pengurus. Hal ini dimaksudkan agar kegiatan atau program yang dilakukan benar-benar bermanfaat bagi masyarakat. Sesuai dengan program khusus yang telah dicanangkan, lembaga ini lebih berkonsentrasi di bidang sosial dan pendidikan. Berjalannya fungsi pengorganisasian dapat dilihat dari adanya susunan struktur organisasi dan pengurus, pendelegasian wewenang dan tanggung jawab yang jelas dan terstruktur yang terdiri dari Dewan Pengurus Syariah, Pengawas Manajemen, struktur manajemen yang meliputi: Ketua, akunting, bendahara dan data, serta ZIS Consultan. Dilihat dari struktur organisasinya, struktur Yatim Mandiri Cabang Lampung termasuk organisasi lini yang bercirikan skala organisasi yang masih kecil, jumlah karyawan yang masih sedikit dan spesialisasi yang masih sedikit pula. Kendalanya adalah ketidaksesuian penempatan posisi karyawan sesuai dengan bidangnya.

Yatim Mandiri melakukan kegiatan kajian pagi sebelum memulai aktivitas. Tujuannya untuk saling bertukar pendapat serta memupuk ikatan emosional antara karyawan. Kegiatan ini juga dapat mempererat ikatan silaturahim antara karyawan Yatim Mandiri Cabang Lampung (Tohari, 2013). Yatim Mandiri Cabang Lampung mempunyai dua pola pengawasan, yaitu pengawasan internal dan pengawasan dari manajerial yaitu bentuk pengawasan yang berasal dari sistem organisasi. Dalam melakukan pengawasan, menajer melakukan evaluasi mingguan untuk melihat hasil kinerja karyawan selama satu minggu. Karyawan diwajibkan membuat laporan mingguan secara tertulis kegiatan yang telah dilaksanakan dalam satu minggu.

\section{Pengelolaan wakaf tunai Yatim Mandiri}

Pendanaan adalah upaya yang dilakukan untuk mendapatkan dana dari sasaran wakif. Dalam pengumpulkan dana, setiap lembaga 
memiliki cara yang berbeda-beda. Cara yang dilakukan Yatim Mandiri adalah dengan menunggu wakif datang secara langsung dan dengan datang secara langsung kepada calon wakif. Hal ini tentunya merupakan tindak lanjut dari adanya sosialisasi yang dilakukan Yatim Mandiri. Dalam sosialisasinya, Yatim Mandiri melakukan promosi melalui berbagai media baik media cetak maupun elektronik. Sumber dana wakaf pada Yatim Mandiri berasal dari para donatur baik donatur tetap maupun donatur tidak tetap. Hingga saat ini, jumlah donasi wakaf pengembangan MBS telah terkumpul senilai Rp 5.739.370.439,00 per Mei 2013. Untuk penerimaan dana terikat pada bulan April 2013 sebesar Rp 292.091.342,00. Yatim Mandiri memberikan pilihan untuk donasi wakaf dimana setiap donasi Rp 200.000 akan membebaskan lahan seluas $1 / 4 \mathrm{~m}^{2}$ dan berlaku kelipatan. Lahan yang sudah dibebaskan oleh donatur Yatim Mandiri cabang Lampung kurang lebih sekitar 1,1/4 $\mathrm{m}^{2}$ mengingat berdirinya Yatim Mandiri Cabang Lampung belum begitu lama (Nurwahyuni, 2013).

Dilihat dari cara pengelolaan oleh nazhir, pengelolaan wakaf tunai di Yatim Mandiri Cabang Lampung termasuk harta wakaf yang dikelola secara semi professional yang mana cara pengelolaannya masih tradisional, namun para pengurus sudah mulai memahami untuk melakukan pengembangan harta wakaf lebih produktif. Namun, tingkat kemampuan dan manajerial nazhir masih terbatas. Pihak Yatim Mandiri sebagai nazhir wakaf masih mengelola dana wakafnya secara tradisional yakni untuk pembebasan lahan dan bangunan dalam rangka mengembangkan sarana dan prasarana sekolah gratis Insan Cendikia Mandiri Boarding School yang berada di wilayah Yatim Mandiri Pusat.

Dalam pendayagunaannya, Yatim Mandiri hanya mengumpulkan dana wakaf tunai yang kemudian dana tersebut diserahkan kepada Yatim Mandiri Pusat untuk dimanfaatkan dalam bentuk pembebasan lahan dan bangunan. Hal ini berbeda dengan $\mathrm{BMH}$ cabang Lampung yang juga mengembangkan lahan yang dibebaskan dengan dana wakaf tunai di daerah kantor cabang berada, sejauh ini Yatim Mandiri hanya melaporkan dan menyerahkan dananya kepada Kantor Pusat yang nantinya dana tersebut digunakan hanya untuk membebasan lahan dan bangunan di daerah lokasi yayasan 
berada, sehingga lahan yang dibebaskan tidak berada di sekitar kantor cabang.

\section{Optimalisasi Wakaf Tunai pada BMH dan Yatim Mandiri}

Aset wakaf di Indonesia dirasa cukup menggembirakan, namun manfaatnya masih belum dapat dirasakan secara maksimal oleh masyarakat Indonesia. Hal ini dilihat dari banyaknya institusi pendidikan, kesehatan, sosial dan lain-lain dibangun berdasarkan aset wakaf namun belum terkelola dengan baik dan berdaya saing. Ini menunjukkan bahwa wakaf mempunyai peran penting dalam menyediakan layanan-layanan bidang pendidikan, kesehatan, sosial, dan lain-lain. Namun banyak hal yang menyebabkan pemanfaatan benda wakaf belum dilakukan secara optimal. Melihat dari kenyataan tersebut, maka perlu diupayakan model perwakafan baru yang cukup baik untuk dikembangkan saat ini yaitu model wakaf tunai.

Pada dasarnya LAZ Baitul Maal Hidayatullah Cabang Lampung dan Yatim Mandiri adalah lembaga sosial keagaman dan juga lembaga swadaya yang memberdayakan wakaf tunai sebagai suatu upaya pengembangan masyarakat Islam/umat sehingga terjadi suatu proses distribusi manfaat bagi masyarakat luas, dari manfaat pribadi menuju manfaat masyarakat luas. Dalam opersionalnya, Baitul Maal Hidayatullah adalah lembaga amal yang bertujuan untuk mendanai beberapa program sebagai upaya mensejahterakan masyarakat yang dalam hal ini kaum dhuafa dan wakaf tunai adalah salah satu instrument yang diaplikasikan dalam upaya untuk mendanai program-program tersebut. Adapun Yatim Mandiri adalah yayasan yang berdiri dengan nama Yayasan Pembinaan dan Pengembangan Panti Asuhan Islam dan Anak Purna Asuh (YP3IS). Lembaga ini konsen pada upaya memandirikan anak yatim dan janda dhuafa yang ada di masyarakat melalui dana ziswaf.

Melihat potensi wakaf tunai yang sangat besar di Lampung, maka tujuan dari didirikannya kedua lembaga tersebut diharapkan akan mendapat respon positif dari masyarakat sekitar. Ditambah lagi dengan adanya kegiatan atau program-program yang dilakukan oleh kedua lembaga tersebut yang dapat memberikan nampak positif dalam membatu perkembangan perekonomian masyarakat serta membantu meringankan beban masyarakat kurang mampu 
yang berada di sekitar lembaga itu berdiri. Oleh karena itu, agar kedua lembaga tersebut mampu optimal dalam mengembangkan wakaf tunai dan mengembangkan masyarakat, maka perlu untuk mengkritisi dari berbagai aspek dalam kedua lembaga tersebut yakni:

1. Aspek manajemen.

Suatu lembaga akan berjalan dengan optimal dan berkembang apabila dikelola dengan baik. Maka dari itu diperlukan suatu pola manajemen yang baik. Adapun dari aspek manajemennya, Baitul Maal Hidayatullah Cabang Lampung dan Yatim Mandiri Cabang Lampung telah melaksanakan fungsi manajemen dengan baik yaitu meliputi fungsi perencanaan, pengorganisasian, pengarahan dan pengawasan, meskipun masih banyak kendalakendala yang dihadapi. Berikut ini akan dijelaskan secara rinci mengenai pola manajerial dari kedua lembaga tersebut.

Tabel: 1

Aspek Managemen BMH dan Yatim Mandiri Cabang Lampung

\begin{tabular}{|c|c|c|c|}
\hline No & $\begin{array}{c}\text { Pola } \\
\text { Manajemen }\end{array}$ & BMH Cabang Lampung & Yatim Mandiri \\
\hline 1 & Perencanaan & $\begin{array}{l}\text { 1.Rapat evaluasi mingguan } \\
\text { dengan tujuan pelaporan } \\
\text { realisasi program rutin. } \\
\text { 2.Rakernas tahunan } \\
\text { 3. Menyusun Rencana Induk } \\
\text { Pengembangan (RIP) dan } \\
\text { Rencana Kegiatan dan } \\
\text { Anggaran (RKAT), }\end{array}$ & $\begin{array}{l}\text { 1.Rapat evaluasi } \\
\text { mingguan dan } \\
\text { pelaporan } \\
\text { realisasi kegiatan } \\
\text { dan perencanaan } \\
\text { kegiatan lanjutan. } \\
\text { 2.Rakernas tahunan }\end{array}$ \\
\hline 2 & $\begin{array}{l}\text { Pengorganisa- } \\
\text { sian }\end{array}$ & $\begin{array}{l}\text { Terbentuknya struktur } \\
\text { organisasi dan pembagian } \\
\text { tanggung jawab dan } \\
\text { wewenang antar pengurus } \\
\text { yang terdiri dari } 4 \text { divisi }\end{array}$ & $\begin{array}{l}\text { Adanya struktur } \\
\text { organisasi } \\
\text { kepengurusan dan } \\
\text { pembagian kerja } \\
\text { yang terdiri dari } 3 \\
\text { bagian. }\end{array}$ \\
\hline 3 & Pengarahan & $\begin{array}{l}\text { Berjalannya fungsi } \\
\text { kepemimpinan dalam BMH } \\
\text { dengan motivasi ketua } \\
\text { kepada karyawan yang }\end{array}$ & $\begin{array}{l}\text { Adanya kegiatan } \\
\text { evaluasi dan kajian } \\
\text { pagi sebagai wadah } \\
\text { untuk memotivasi }\end{array}$ \\
\hline
\end{tabular}




\begin{tabular}{lll}
\hline & dituangkan dalam rapat & dan membangun \\
& evaluasi mingguan dan & ikatan yang kuat \\
& kegiatan diluar lembaga. & antar karyawan \\
& 1.Pengawasan internal & Pengawasan \\
& 2.Pengawasan eksternal & eksternal dengan \\
& dilakukan dengan adanya & mengamati laporan \\
& pelaporan hasil kinerja & kinerja harian yang \\
& divisi selama satu minggu. & dibahas dalam \\
& & rapat evaluasi \\
Pemilihan & Penempatan posisi divisi & mingguan. \\
Insani & Penempatan \\
& Kepala cabang tidak berhak & karyawan cabang \\
& dipilih oleh \\
& divisinya. & kepala cabang. \\
& & Kepala cabang \\
& & berhak melakukan \\
& seleksi karyawan \\
& sesuai dengan \\
& keilmuannya. \\
\hline
\end{tabular}

Sumber: Data terolah

Dalam fungsi perencanaan, aspek penting yang menjadi kendala pada Yatim Mandiri adalah orang atau pengurus yang melakukan perencanaan. Hal ini disebabkan oleh tidak konsistennya keanggotaan pengurus khususnya dibidang Zis Consultant. Adapun dalam pelaksanaan fungsi pengorganisasian, adanya ketidaksesuain penempatan posisi karyawan menjadi salah satu kendala dalam kedua lembaga tersebut. Karena demi berjalannya fungsi ini dengan baik maka dibutuhkan individuindividu yang tepat sesuai dengan divisi atau bagian yang diembannya.

Dalam penentuan sumber daya insaninya, setiap lembaga memiliki prosedur yang berbeda. Pengurus pada BMH cabang Lampung dipilih langsung oleh BMH Pusat sehingga kepala cabang tidak memiliki wewenang untuk menentukan anggota pengurusnya. Ini memunculkan kelemahan yakni ketika terdapat ketidaksesuain SDM dengan bidang yang diemban sehingga program kerja yang dilaksanakan tidak berjalan dengan efektif. 
Berbeda dengan Yatim Mandiri yang menyerahkan sepenuhnya seleksi kepengurusan kepada kepala cabang melalui beberapa tahapan penyeleksian.

2. Sistem pengelolaan.

Selain dari aspek manajerialnya, untuk tercapainya tujuan program wakaf tunai di lembaga sosio-ekonomi keagamaan yaitu pada Baitul Maal Hidayatullah Cabang Lampung dan Yatim Mandiri, maka diperlukan sistem pengelolaan yang baik dan terencana. Dalam pengelolaan wakaf tunai terdapat dua langkah yang harus dilaksanakan oleh kedua lembaga tersebut. Langkah pertama yaitu proses pendanaan atau penghimpunan dana dari masyarakat mampu yang nantinya digunakan untuk membiayai kegiatan yang ada di lembaga. Adapun langkah kedua yaitu proses pendayagunaan yang berarti kemampuan untuk mendatangkan hasil dan manfaat. Berikuti ini pola pendanaan dan pendayagunaan wakaf tunai pada BMH cabang Lampung dan Yatim Mandiri Cabang Lampung.

Tabel: 2

Sistem Pengelolaan BMH dan Yatim Mandiri Cabang Lampung

\begin{tabular}{clc}
\hline No Pengelolaan & BMH Cabang Lampung & Yatim Mandiri \\
\hline 1. Pendanaan & 1.Menunggu wakif & 1.Menunggu bola yaitu \\
& yang datang dengan & dengan menunggu wakif \\
& sukarela untuk & datang langsung untuk \\
& mendonasikan & mendonasikan dananya. \\
& dananya. & 2.Jemput bola yaitu \\
& 2.Melakukan langkah & dengan datang secara \\
& persuasif. & langsung kepada wakif \\
& & yang dianggap mampu \\
& & untuk mendonasikan \\
& & dananya. \\
Pendayagu- & 1.Metode pembiayaan & 1.Metode pembiayaan \\
naan & tradisional. & tradisional. \\
& 2.Pembebasan lahan & 2.Pembebasan lahan \\
& sebagai sarana & dan bangunan sebagai \\
& pendidikan pada & sarana pendidikan gratis \\
& yayasan Hidayatullah & unggulan Insan Cendikia \\
& untuk mendukung & Mandiri. \\
\hline
\end{tabular}




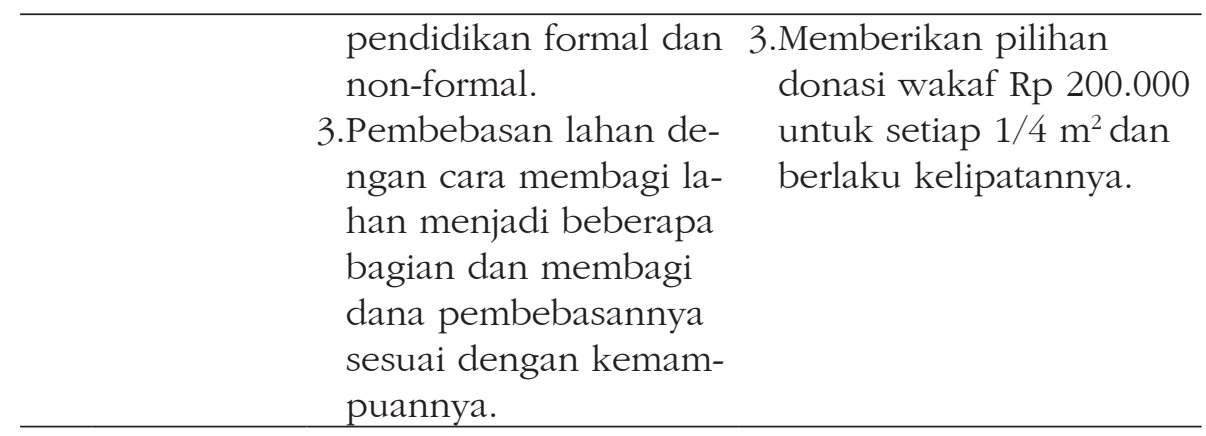

Sumber: Data terolah

Dalam pelaksanaan proses pendanaan dan pendayagunaannya, BMH Cabang Lampung dan Yatim Mandiri pada dasarnya memiliki mekasisme yang sama. Hanya saja wakaf tunai yang dikembangkan pada kedua lembaga tersebut masih bersifat tradisional dan konsumtif karena model pembiayaannya berupa pembiayaan dengan menciptakan wakaf baru yang bertujuan untuk melengkapi inventaris aset wakaf yang telah ada. Jika dilihat dari potensinya, dana wakaf tunai hendaknya dapat dikelola secara lebih produktif sehingga manfaat pengelolaan harta wakaf dapat memberikan kontribusi yang lebih besar dalam memberdayakan masyarakat, baik di bidang pendidikan, ekonomi, sosial, kesejahteraan masyarakat maupun dakwah.

Pada dasarnya potensi wakaf tunai yang cukup besar, membuka peluang bagi seluruh umat Islam Indonesia untuk berwakaf. Dengan wakaf tunai setiap orang Islam dapat mewakafkan hartanya dengan tidak dibatasi jumlah dan besarannya. Dapat diperkirakan dengan mengasumsikan sekitar 88 persen dari jumlah penduduk Indonesia (237.556.363 orang) adalah umat Islam (BPS, 2010: 6), mengeluarkan wakaf tunai sebesar 10 ribu rupiah, maka dana yang terkumpul sebesar 2,08 triliun rupiah, jumlah yang sangat besar untuk membiayai pemberdayaan masyarakat. Dana tersebut dapat diaplikasikan dengan membuat program pemberdayaan penduduk miskin dengan memberikan pembiayaan usaha sebesar 10 juta/ keluarga maka akan ada 200.000 usaha mikro kecil menengah yang akan tumbuh. Dapat diharapkan usaha mikro kecil menengah tersebut akan tumbuh mandiri karena tidak terikat oleh bantuan 
pemerintah dan bunga yang tinggi dari renternir, sehingga disamping memberdayakan masyarakat miskin wakaf juga secara ekonomik memutus praktek bunga di masyarakat (Murat Cizakca, 1998:44-45).

Dengan adanya wakaf tunai membuka peluang bagi kemanfaatan harta wakaf yang lebih luas, terutama bagi terciptanya keadilan ekonomi yang dapat dilakukan dengan menyalurkan dana wakaf pada investasi. Hasil yang diperoleh dari investasi dana wakaf misalnya dapat digunakan untuk mendirikan lembaga pendidikan dan latihan kerja, bagi masyarakat miskin agar mereka dapat meningkatkan keterampilan (skill) sehingga mampu bersaing pada lapangan kerja.

Di samping itu, hasil yang terkumpul dari wakaf tunai juga dapat digunakan untuk mendirikan lembaga keuangan mikro syariah, yang dapat membantu permodalan usaha kecil. Mendirikan bank wakaf yang dapat diakses oleh seluruh rakyat baik untuk pembiayaan modal usaha maupun investasi. Di samping itu, kemanfaatan harta wakaf juga dapat digunakan untuk mendirikan sarana pendidikan, lembaga advokasi dan bantuan hukum, serta guna menciptakan sarana kesejahteraan sosial masyarkat yang lebih luas agar tercipta keadilan distribusi di masyarakat. Jika seluruh hal tersebut dilakukan, secara langsung akan meningkatnya kualitas pembangunan manusia Indonesia dan pada akhirnya, secara berlahan namun pasti akan berdampak pada pemberdayaan masyarakat dengan menurunnya jumlah pengguran dan kemiskinan yang ada.

Masalah kemanfaatan wakaf di Indonesia terbentur oleh pemahaman mayoritas umat Islam Indonesia yang masih beranggapan bahwa wakaf keagamaan lebih penting dari pada wakaf untuk tujuan pemberdayaan sosial. Oleh karena itu, lebih banyak masyarakat mempraktekan wakaf keagamaan, seperti wakaf untuk masjid, musalla, makam dan sebagainya. Sebaliknya wakaf untuk tujuan pemberdayaan, seperti wakaf guna pemberdayaan ekonomi, pendidikan dan kesejahteraan masyarakat yang lebih luas belum dipandang penting (M Cholil Nafis, 2008).

Pada dasarnya jika dilihat dari substansi ajaran wakaf yang terletak pada nilai kemanfaatan harta wakaf bagi kepentingan umat 
(social benefit). Maka kesinambungan harta wakaf semakin menjadi jaminan agar harta tersebut tidak berkurang. Bahkan sebaliknya, harta wakaf dapat berkembang jika dikelola dengan baik dan memberikan kemanfaatan yang lebih luas sesuai dengan perannya sebagai instrumen dalam pemberdayaan ekonomi masyarakat. Oleh sebab itu, dibutuhkan peran aktif banyak pihak; pemerintah, ulama, akademisi, dan berbagai pihal lainnya, untuk bekerjasama dan mensosialisasikan wakaf sebagai bagian dari upaya pemberdayaan sosial ekonomi masyarakat agar tercipta pemahaman yang lebih baik tentang wakaf sebagai instrumen redistribusi di masyarakat.

\section{Kesimpulan}

Dari data dan analisa yang telah dipaparkan di atas, dalam mengoptimalkan pengelolaan wakaf tunai baik pada aspek manajemen dan pengelolaan (pendanaan dan mendayagunaannya) pada Lembaga Baitul Mal Hidayatullah dan Yatim Mandiri. Pada aspek manajemen baik BMH maupun Yatim Mandiri menjalankan fungsi perencanaan, pengorganisasian, pengarahan dan pengawasan, meskipun masih banyak kendala-kendala yang dihadapi sperti halnya SDM yang tidak sesuai dengan keahliannya serta mengangkatan pegawai tang terpusat pada BMH mengakibatkan lambannya proses pemberdayaan ekonomi masyarakat. Oleh sebab itu, perbaikan pada sistem manajemen yang dilakukan oleh setiap lembaga menjadi sangat penting untuk diterapkan.

Pada aspek pengelolaan, proses pendanaan dan pendayagunaannya, BMH Cabang Lampung dan Yatim Mandiri pada dasarnya memiliki mekasisme yang sama. Hanya saja wakaf tunai yang dikembangkan pada kedua lembaga tersebut masih bersifat tradisional dan konsumtif sehingga pengembangan ekonomi masyarakat menjadi terhambat. Hal ini bertenangan dengan semangat wakaf tunai memiliki tingkat fleksibilitas yang sangat tinggi, artinya wakaf tunai dapat dikembangkan dengan berbagai kegiatan usaha produktif masyarakat sehingga memberikan peluang yang besar dalam memberdayakan ekonomi masyarakat. 


\section{Daftar Pustaka}

Anshori, Abdul Ghafur. 2006. Hukum dan Praktek Perwakafan di Indonesia, Yogyakarta: Pilar Media.

Abu Sinn, Ahmad Ibrahim. 2006. Manajemen Syariab Sebuab Kajian Historis dan Kontemporer, Jakarta: PT RajaGrafindo Persada.

Al-Hasyimi. tt. Mukhtaral-Hadis wa al-Hukmu al-Muhammadiyyah, Cairo: Daar an-Nasyr al-Misriyyah.

Basyir, Ahmad Azhar. 1977. Hukum Islam tentang Wakaf, Ijarah, Syirkah, cet. ke-1, Bandung: PT al-Ma'arif.

Chamidah, Umi. 2008. Pengelolaan Aset Wakaf Tunai pada Lembaga Keuangan Syariah (Studi Pengelolaan Wakaf Tunai di Baitul Maal Hidayatullah Malang), Skripsi, UIN Malang.

Cizakca, Murat. 1998. "Awqof in History and Its Implications For Modern Islamic Economic", dalam Jurnal Islamic Economic Studies, Vol.6, No. 1.

Departemen Pendidikan dan Kebudayaan. 1998. Kamus Besar Bahasa Indonesia, Jakarta: Balai Pustaka.

Direktorat Pemberdayaan Wakaf. 2007. Pedoman Pengelolaan Wakaf Tunai, Jakarta: Direktorat Jenderal Bimbingan Masyarakat Islam.

Fadhilah, Nur. 2009. Wakaf Tunai: Potensi dan Alternatif Pengelolaan, Junal Abkam, Volume 11 Nomor 2.

Fanani, Muhyar. 2010. Berwakaf Tak Harus Kaya, Dinamika Pengelolaan Wakaf Uang di Indonesia, Semarang: Wali Songo Press.

Husna, Sarmidi. 2013. "Wakaf Uang", http://ekisopini.blogspot. com/2010/03/wakaf-uang.html.

Hafidhuddin, Didin dan Hendri Tanjung. 2003. Manajemen Syariah dalam Praktik, Jakarta: Gema Insani Press.

Mannan, Muhammad Abdul. 2001, Sertifikat Wakaf Tunai Sebuah Inovasi Instrumen Keuangan Islam, Depok: CIBER-PKTTI-UI.

Mughniyah, Muhammad Jawad. 1996. Fiqh Lima Mazhab: Ja'fari, Hanafi, Syafi'I, Hambali, alih bahasa Masykur A.B., dll., Jakarta: Lentera. 
Nasution (ed.), Hasanah (ed.). 2006. Wakaf Tunai-Inovasi Finansial Islam, cet. Ke-2 Jakarta: Program Studi Timur Tengah dan Islam UI.

Praja, Juhaya S. 1997. Perwakafan di Indonesia, Sejarah, Pemikiran, Hukum dan Perkembangannya, cet. ke-3, Bandung: Yayasan Piara.

Saidi, Zaim dan Hamid Abidin. 2005. Menjadi Bangsa Pemurah, Wacana dan Praktek Kedermawanan Sosial di Indonesia, Jakarta: PIRAC,

Wadjdy, Farid dan Mursyid. 2007. Wakaf dan Kesejahteraan Umat (Filantropi Islam yang hampir terlupakan, Yogyakarta: Pustaka Pelajar. 